\title{
Changes in Land Use Affect Dependable Discharge in the Miu River Basin
}

\author{
Rudi Herman $^{1 *}$, Vera Wim Andiesse ${ }^{1}$, Siti Rahmi Oktaviana ${ }^{1}$ \\ ${ }^{1}$ Civil Engineering, Faculty of Engineering, Tadulako University, Palu, Central Sulawesi Indonesia
}

\begin{abstract}
Land use changes in a watershed will affect to net rainfall and have an impact to river discharge. Evaluation of plant interception due to land use changes would had better view of net rainfall. The descriptive research is aims to determine changes in land use that affect net rainfall and reliable discharge using the Nreca calculation model. The area of the Miu watershed was $654.55 \mathrm{~km}^{2}$ and the changes in land use was considered the years of 2005, 2010 and 2016 which is observed by using ArcGIS software to evaluate the catchments area. The land use changes show the forest area decrease from $82.10 \%$ in 2005 to 78.65 and $89.67 \%$ for 2010 and 2016, but there has been a lot of increase in open area from $1.71 \%$ in 2005 to $8.19 \%$ in 2016. Net rainfall was applied in calculation of dependable discharge and the results obtained show the flow consistency. The input parameter for initial SMS is $200 \mathrm{~mm}$, PSUB is 0.85 and GWF is 0.25 . The average discharge obtained is $9.15 \mathrm{~m}^{3} / \mathrm{sec}$. The graph shows very close relationship between net rainfall that influencing to dependable discharge.
\end{abstract}

\section{Introduction}

The river's flow is highly dependent on climatology and soil conditions and the vegetation that supports the retention of water. Land use changes as well as an increase in temperature will have a direct impact on the flow of the river and debit. Human exploitation of land within the watershed is based on human needs for plantation and agricultural land. Uncontrolled land needs cause watershed conditions physically and environmentally to decline. One of the phenomena of decreasing watershed conditions is land use change caused by land conversion. By the increasing change in land use in the watershed, a study is needed to determine the impact of changes in land use on dependable discharge.

The search for effective problem solving has been carried out by various parties with several approaches. One approach is to do modelling to determine the behavior of rain due to changes in land use in the watershed. Furthermore, with net rainfall it will be easy to analyse the mainstay discharge on the river. By using modelling, future river behavior can be predicted based on trends that occur now and, in the past, so that the effect of treatment on the river can be known.

\footnotetext{
*Corresponding author: rudi.herman2@email.org
} 
The Miu watershed is in the Omu Village, Gumbasa District, Sigi District, Central Sulawesi. From the evaluation of land use change using ArcGIS software for the 2005, 2010 and 2016 studies, the percentage change in land use in the Miu watershed, namely for the study of forest land in 2005-2016, has decreased land area. Whereas plantation land has increased as well as rice fields, agricultural areas, shrubs, settlements, and water bodies. From these data we can see that changes in land use each year have a change.

Knowing the impact of rainfall variability and land conversion on river flow discharge is essential to ensure the sustainability of water resources. Therefore, modelling is raindischarge unit to approach the values of hydrological processes that occur in the field are required. The availability of Flow data, rainfall data and climatological data is needed to determine the potential of water resources in a river basin. Rain-flow models can be used as a tool to monitor and evaluate the potential of river discharge through the approach of the existing surface water resources [1-3].

\section{Literature Review}

\subsection{Watershed}

Watershed is an area where all the water flows into a river. This area is generally restricted by topography, which means determined based on the flow of surface water. For modelling purposes, the basin is divided into hydrologic response units (HRU) and subbasins. These are the basic units of water balance calculation and enable the model to accurately simulate the spatial variation of water balance components [2]. Water balance is a balancing system of water in one place at a certain period, so that the information excess (surplus) or shortage (deficit) of water can be easily to know. The concept of water balance basically shows the balance between the amount of water if flow, available, and outflow from the specific system. In general, the water balance equation formulated.

$$
I=O \pm \Delta S
$$

Where, $I$ am an input (inflow); $O$ is an output (outflow); and $\Delta S$ is a change in soil moisture content.

\subsection{Nreca Methods}

In the analysis of the dependable flow the amount of discharge is calculated using the Nreca simulation model. Nreca's principle is to estimate the amount of river flow due to rainfall in the catchment area by considering the soil conditions and topography of the catchment. In the model there are two types of storage, namely moisture storage and groundwater storage. The water balance equation is stated as follows;

$$
R O=R-E t a+\Delta S
$$

Input is needed from the model of rain - runoff are as follows; The average rainfall (P);

Potential evapotranspiration (PET); The capacity of the storage moisture (NOM); PSUB (values ranging from $0.3-0.9$ ); GWF (ranged from $0.2-0.8$ ); The initial value of the storage soil moisture (SMSTOR); The initial value of the ground water reservoir (GWSTOR); and Crop factor (Cf). 


\subsection{Net Rainfall in Catchment Area}

Rainfall intensity is defined as the ratio of the total amount of rain (rainfall depth) falling during a given period to the duration of the period It is expressed in depth units per unit time, usually as mm per hour $(\mathrm{mm} / \mathrm{h})$. The statistical characteristics of high-intensity, shortduration, convective rainfall is essentially independent of locations within a region and are similar in many parts of the world. Net Rainfall is a portion of rainfall which reaches a stream channel or the concentration point as direct surface flow.

Land use changes such as the conversion of forest to agricultural land, agricultural land to residential areas and others will have an impact on the environment, especially on surface watersheds. Land use has impact to the net rainfall due to interception of canopy crops in the watershed. This equation is used to obtain net rainfall on each land use.

Calculation of net rainfall was adopting the formula [3] which is the application of Dunne and Leopold, 1978.

Net rainfall for area excepting forest $Y=0,925 x+0,333$ and $R 2=0,996$

Net rainfall for forest used the formula: $Y=0,886 x+0,088$ and $R 2=0,996$

\subsection{Evapotranspiration}

Evaporation is the process whereby liquid water is converted to water vapour (vaporization) and removed from the evaporating surface (vapour removal). Water evaporates from a variety of surfaces, such as lakes, rivers, pavements, soils and wet vegetation. Evapotranspiration (ET) is the combined processes of evaporation of water from the soil surface and plant surfaces and transpiration of water through the plant tissues. Evapotranspiration is the total amount of water that is returned to the atmosphere from the surface of the ground, bodies of water and vegetation by the influence of climatic factors and physiological vegetation [1]. Generally potential parameters for evapotranspiration calculation are 1) The average monthly temperature; 2) monthly relative humidity average $(\mathrm{RH})$; 3) The monthly sun brightness ( $\mathrm{n} / \mathrm{N}$ in percent); 4) monthly wind rate average (U in $\mathrm{m} / \mathrm{s}$ ); 5) Location of latitude regions; 6) The number of correction (C).

The Calculation of potential evapotranspiration using Penman Modification Method received a recommendation from the UN Food and Agriculture Organization. The general principle of the calculation of potential evapotranspiration in accordance with the following formulation:

$$
E=C *(W * R n+(1-W) * f(u) *(e a-e d))
$$

Where; $\mathrm{E}$ is a daily potential evapotranspiration ( $\mathrm{mm} /$ day); $\mathrm{C}$ is a correction factor; $\mathrm{W}$ is a weighting factor; $\mathrm{Rn}$ is a net radiation (Rnl- RNS); $\mathrm{f}(\mathrm{u})$ is a function of wind speed; ea is a saturated vapour pressure and ed is an actual vapour pressure.

\section{Research Methodology}

\subsection{Research Site}

This study is administratively located in Omu Village, Gumbasa sub district, Sigi Central Sulawesi Regency with a geographical location of $1^{\circ} 16^{\prime} 44.36$ "S and $119^{\circ} 56^{\prime} 40.54^{\prime \prime E}$. This research is a kind of descriptive research that aims to determine land use changes that affect the dependable discharge in the Miu River Basin using the Nreca model. 


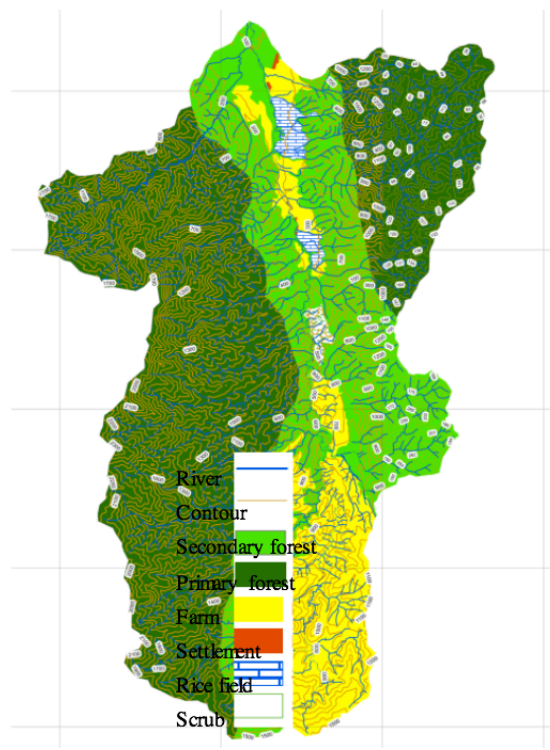

Fig.1. Research locations in the Miu watershed in 2005.

\subsection{Research Data}

The material used in this study is secondary data. The data is the result of measurements, records and research obtained from various relevant agencies. The data used are:

1. The topographic data obtained is a sheet of earth representing the Miu watershed with Scale 1: 80000 in 2005, 2010 and 2016 [4].

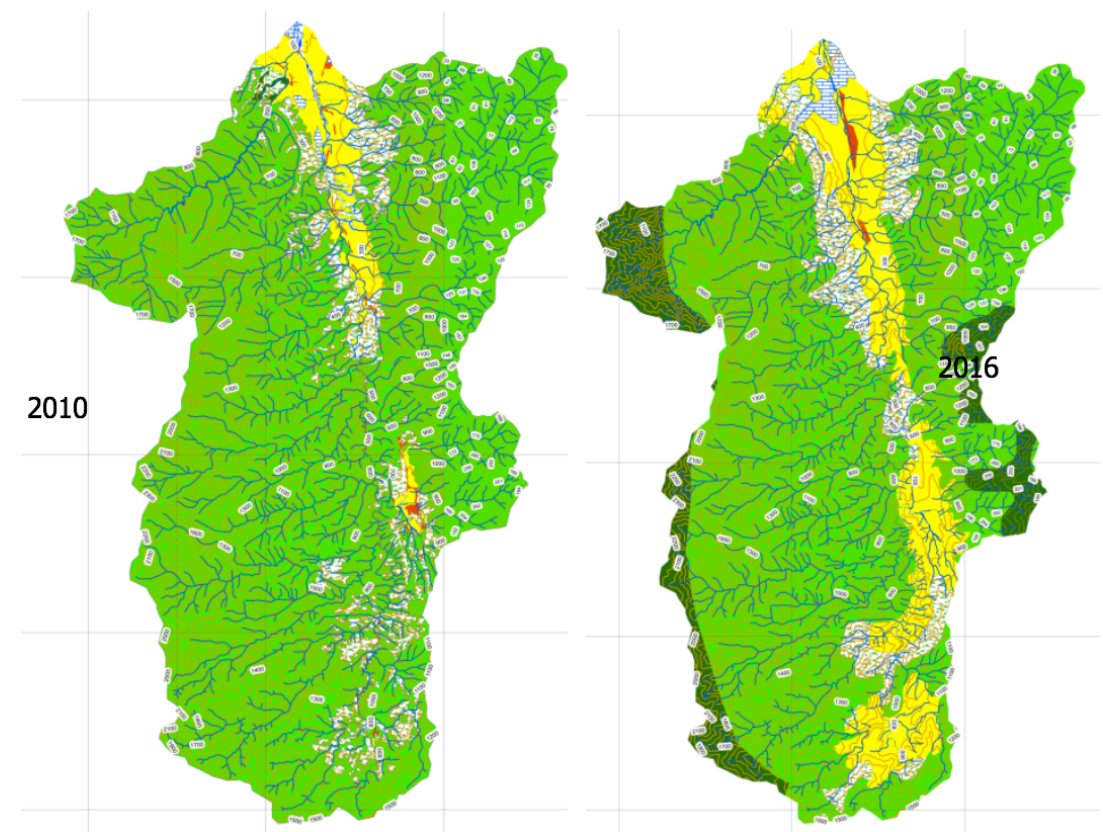

Fig.2. Changes of Miu Watershed from 2005, 2010 and 2016 
Table 1. Land use changes from 2005 to 2010 and 2016

\begin{tabular}{|c|c|c|c|c|c|c|c|}
\hline \multirow{2}{*}{ No } & \multirow{2}{*}{$\begin{array}{c}\text { Land use } \\
\text { Type }\end{array}$} & \multicolumn{2}{|c|}{$\mathbf{2 0 0 5}$} & \multicolumn{2}{c|}{$\mathbf{2 0 1 0}$} & \multicolumn{2}{c|}{$\mathbf{2 0 1 6}$} \\
\cline { 3 - 8 } & & $\begin{array}{c}\text { Area } \\
(\mathbf{k m 2})\end{array}$ & $\mathbf{\%}$ & $\begin{array}{c}\text { Area } \\
\mathbf{( k m 2 )}\end{array}$ & $\mathbf{\%}$ & $\begin{array}{c}\text { Area } \\
(\mathbf{k m 2})\end{array}$ & $\%$ \\
\hline 1 & Forest & 537,41 & 82,10 & 515,59 & 78,65 & 587,83 & 89,67 \\
\hline 2 & Plantation & 105,92 & 16,18 & 83,19 & 12,69 & 14,01 & 2,14 \\
\hline 3 & Open Field & 11,22 & 1,71 & 56,77 & 8,66 & 53,71 & 8,19 \\
\hline
\end{tabular}

2. Monthly rainfall data from 2005 - 2016 were obtained from the Sulawesi River Region III, and the data can be seen in the table below.

Table 2. Monthly Rainfall Data

\begin{tabular}{|c|c|c|c|c|c|c|c|c|c|}
\hline \multirow{2}{*}{ Month } & \multicolumn{7}{|c|}{ Years } \\
\cline { 2 - 10 } & $\mathbf{2 0 0 5}$ & $\mathbf{2 0 0 6}$ & $\mathbf{2 0 0 7}$ & $\mathbf{2 0 0 8}$ & $\mathbf{2 0 0 9}$ & $\ldots$ & $\mathbf{2 0 1 4}$ & $\mathbf{2 0 1 5}$ & $\mathbf{2 0 1 6}$ \\
\hline Jan & 87 & 60 & 183,1 & 70,2 & 42 & $\ldots$ & 129,8 & 67 & 163,3 \\
\hline Feb & 119 & 77 & 180,6 & 67,3 & 131 & $\ldots$ & 71,4 & 116,7 & 170,8 \\
\hline Mar & 297 & 107 & 263,6 & 268,8 & 139 & $\ldots$ & 150 & 226,8 & 141,2 \\
\hline Apr & 236 & 238 & 208,1 & 314,5 & 174 & $\ldots$ & 106,1 & 237,2 & 249,8 \\
\hline May & 285 & 156 & 371,5 & 152,3 & 68 & $\ldots$ & 381,1 & 95,8 & 151,5 \\
\hline Jun & 184 & 140,9 & 178,7 & 185 & 73 & $\ldots$ & 176,2 & 110,3 & 361,1 \\
\hline July & 253 & 186,9 & 71,3 & 289,2 & 120 & $\ldots$ & 98,1 & 70 & 148 \\
\hline Augt & 57 & 68,3 & 212,6 & 247 & 172 & $\ldots$ & 77 & 68,5 & 134,8 \\
\hline Sep & 147 & 236,5 & 114,7 & 64 & 34 & $\ldots$ & 109 & 71,5 & 171,6 \\
\hline Oct & 293 & 12 & 205,7 & 281 & 115 & $\ldots$ & 100,5 & 63,6 & 229,24 \\
\hline Nov & 187 & 115 & 80,6 & 97 & 85 & $\ldots$ & 89,4 & 192,7 & 168,59 \\
\hline Des & 110 & 204,8 & 220,2 & 56 & 300 & $\ldots$ & 88,4 & 33,3 & 195,71 \\
\hline Total & 2255 & 1602,4 & 2290,7 & 2092,3 & 1453 & $\ldots$ & 1577 & 1353,4 & 2285,6 \\
\hline Average & 187,92 & 133,53 & 190,89 & 174,36 & 121,08 & $\ldots$ & 131,42 & 112,78 & 190,47 \\
\hline
\end{tabular}

3. Time series of daily temperature $(\mathrm{T})$, relative humidity $(\mathrm{RH})$, wind speed $(\mathrm{W})$ and precipitation $\mathrm{R}$ obtained from the Climatological of Tuva Station, Meteorology Climatology and Geophysics Agency (BMKG) Bandara Mutiara Sis Aljufri, Palu Centre Sulawesi. It taken from 2005 to 2016. The data tabulated in the table 3.

Table 3. Average Climatology Data at Tuva Station

\begin{tabular}{|c|c|c|c|c|c|}
\hline No & Month & $\begin{array}{c}\text { Temperature } \\
\mathbf{t}(\mathbf{C})\end{array}$ & $\begin{array}{c}\text { relative } \\
\text { humidity }\end{array}$ & $\begin{array}{c}\text { wind rate } \\
(\mathbf{k m} / \mathbf{d a y}\end{array}$ & $\begin{array}{c}\text { solar } \\
\text { radiation } \\
\mathbf{n} / \mathbf{N}(\%)\end{array}$ \\
\hline 1 & January & 27,13 & 75,6 & 14 & 46,9 \\
\hline 2 & February & 26,82 & 77,5 & 15 & 65 \\
\hline
\end{tabular}




\begin{tabular}{|c|c|c|c|c|c|}
\hline 3 & March & 26,87 & 78 & 15 & 55,3 \\
\hline 4 & April & 26,97 & 79,7 & 14 & 43,7 \\
\hline 5 & May & 27,48 & 77 & 15 & 61,7 \\
\hline 6 & June & 27,42 & 75 & 14 & 61,9 \\
\hline 7 & July & 26,69 & 75,9 & 15 & 52 \\
\hline 8 & August & 28,05 & 73,3 & 16 & 50,1 \\
\hline 9 & September & 28,75 & 69,4 & 18 & 64 \\
\hline 10 & October & 28,16 & 71,1 & 18 & 55,5 \\
\hline 11 & November & 28,49 & 72,5 & 16 & 64,2 \\
\hline 12 & December & 27,86 & 74,2 & 16 & 46,2 \\
\hline
\end{tabular}

\subsection{Research Design}

A research design [5] is the set of methods and procedures used in collecting and analyzing measures of the variables specified in the problem research. The design of a study defines the study type (descriptive, correlation, semi-experimental, experimental, review, metaanalytic) and sub-type (e.g., descriptive-longitudinal case study), research problem, hypotheses, independent and dependent variables, experimental design, and, if applicable, data collection methods and a statistical analysis plan.

Therefore the research was design as follows; 1) Calculation of evapotranspiration using the Penman Modification method, 2) Calculate the percentage of land use change in Miu watershed by using ArcGIS. 3) Changes in rainfall due to the influence of land use (mm), 4) Calculation of net rainfall, 5) Dependable discharge calculations using the NRECA method.

\section{Result and Discussion}

Nreca method was used to calculate a dependable discharge while the input used for rainfall is net rainfall as a result of changes in land use. The evapotranspiration was used a modified penmann formula. Net rainfall corresponds to the water infiltrated through the soil layer and is the actual input signal of the showed that Soil-water balance approach is an accurate way to estimate net rainfall [6].

\subsection{Calculation of Net Rainfall}

Net rainfall computations with Soil-water balance depend mainly on vegetative cover interception, surface runoff, available soil water storage capacity (AWS) and evapotranspiration. The types of landuse consist of primary dryland forest, secondary dryland forest, ricefield area, plantation area, shrubs, settlement and body of water. For example, in 2016 the value of the largest net rainfall occurred in June of $324.97 \mathrm{~mm} /$ month. The largest for all types of land use except for secondary dryland forest which occurred in October was $200.30 \mathrm{~mm} /$ month.

From the calculation of monthly net rainfall from 2005 to 2016, it can be seen that the largest average monthly net rainfall occurred in 2010 amounted to $194.91 \mathrm{~mm} /$ month and the lowest occurred in 2015 amounted to $101,98 \mathrm{~mm} /$ month. The highest monthly net rainfall occurred in August 2010 amounted to $288.77 \mathrm{~mm} /$ month. 


\subsection{Calculation of Evapotranspiration}

The penman formula is a semi-empirical equation combining mass transfer (Ea) and energy budget $(\mathrm{H})$ methods. The formula was developed by Penman in 1948 and is still widely used for calculating the potential evaporation using synoptic meteorological data such as temperature, wind rate, solar radiation, relative humidition, saturated vapor pressure, extra solar radiation, maximum solar radiation and temperature effect. For example, in 2010 the largest value of Potential Evapotranspiration (ETo) with the Modified Penman Method occurred in November of $167.66 \mathrm{~mm} /$ month. The highest average monthly Potential Evapotranspiration (ETo) with Modification Penman Method from 2005 to 2016 occurred in November of $138.12 \mathrm{~mm} /$ month and the smallest occurred in June of $98.67 \mathrm{~mm} /$ month.

\subsection{Calculation of Dependable Discharge}

Calculation of discharge was used an evapotranspiration and net rainfall that occurs in Omu watershed. The Calculation of potential evapotranspiration using Penman Method and the amount of discharge was using simulation models Nreca. Nreca principle is to estimate the amount of river flow due to the rain that fell in the Catchment Area taking into account the soil conditions and topography of the catchment. The parameter that should be concern are PSUB and GWF which has significant impact to the discharge result therefore the input parameter for initial SMS is $200 \mathrm{~mm}$, PSUB 0.85 and GWF $=0.25$. For example in 2010 the largest dependable discharge of Miu River by Nreca's method occurred in August of $16.12 \mathrm{~m} 3 / \mathrm{sec}$ and the lowest in January of $608 \mathrm{~m} 3 / \mathrm{sec}$.

The method of calculation carried out for water availability uses monthly rainfall data and evapotranspiration to calculate monthly debits. The dependable discharge calculation in the table above shows the steps of the Nreca method. And the results of the debit calculation are also shown every month. Overall, from the analysis Dependable Discharge of the Nreca method, the biggest discharge value is $29.00 \mathrm{~m} 3 / \mathrm{sec}$ occurred in December 2012, and the smallest discharge is $1.26 \mathrm{~m} 3 / \mathrm{sec}$ occurred in April 2012.

The results of the calculation of the dependable discharge shown in graphical form to show the mainstay discharge trend from 2005 - 2016 due to changes in land use.

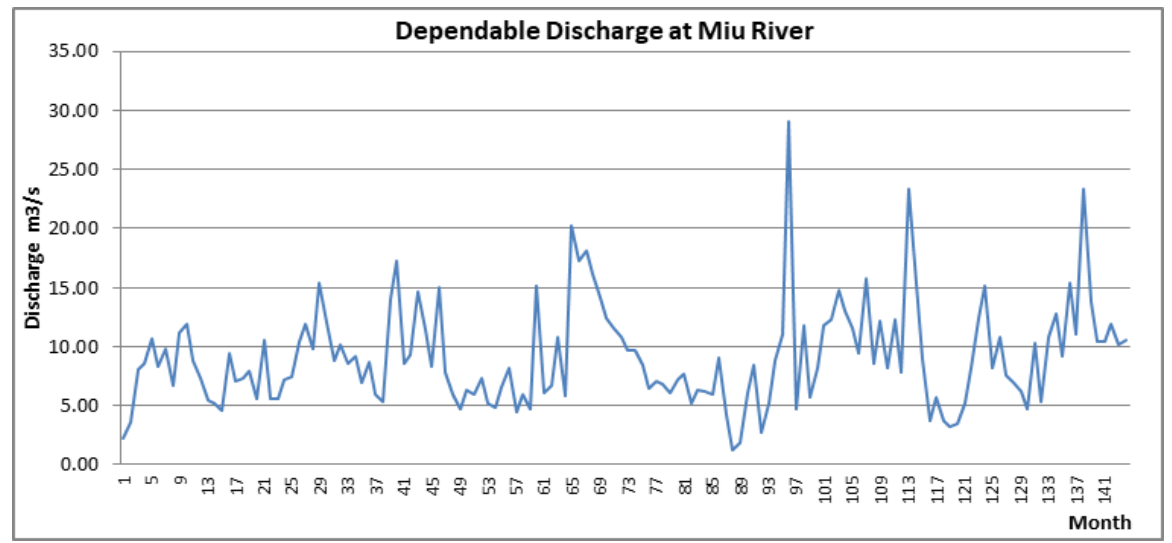

Fig.3. The results dependable discharge analysis due to changes in land use .

In Figure 3 shows the stability of discharge flow from 2005 - 2016. This result is quite good because the expected discharge is still relatively good. From the results of observations of a large area of watershed and extensive forest land, it will maintain flow stability. 


\section{Conclusion}

In analysis a dependable discharge, it should use net rainfall obtained from evaluating land use changes. For the Omu watershed, which was evaluated from 2005-2016, there was a change in the function of forest area but was not significant. This can be seen from the stability of the mainstay discharge in the Omu watershed. The results obtained by the Nreca model show a very good discharge graph where the average discharge reaches $8.03 \mathrm{~m} 3 / \mathrm{sec}$ from 2005-2010, while for the years 20011-2016 the average mainstay discharge reaches $7.89 \mathrm{~m} 3 / \mathrm{sec}$. The parameter of PSUB is 0,85 while the GWF parameter is 0.25 . The biggest discharge value is $29.00 \mathrm{~m} 3 / \mathrm{sec}$ occurred in December 2012, and the smallest discharge is $2.28 \mathrm{~m} 3 / \mathrm{sec}$ occurred in January 2005.

\section{References}

1. Asdak, C. Hydrology and Watershed Management. UGM-Press, Yogyakarta (2007).

2. Patwardhan, A. S., Nieber, J. L., \& Johns, E. L. Effective rainfall estimation methods. Journal of Irrigation and Drainage Engineering, 116(2), 182-193 (1990).

3. I Wayan Sutapa, Pengaruh Perubahan Iklim Terhadap Permodelan Debit (2013)

4. Faza Ramadhani, Dependable Flow and Flood Control Performance of Logung Dam, Central Java Province, Indonesia, Journal of the Civil Engineering Forum, Vol. 3 No. 2 May (2017)

5. M. H. Ali and S. Mubarak (2017), Effective Rainfall Calculation Methods for Field Crops: An Overview, Analysis and New Formulation, Asian Research Journal of Agriculture, 7(1): 1-12 (2017)

6. Vallet, C. Bertrand, O. Fabbri, and J. Mudry (2015), An efficient workflow to accurately compute groundwater recharge for the study of rainfall-triggered deepseated landslides, application to the Séchilienne unstable slope (western Alps), Hydrol. Earth Syst. Sci., 19, 427-449 (2015) 